\title{
Distribution of Fire Cases and the Role of Human Factors in Coal-Firing Power Plants in Fuel-Supply Fields and Distribution Systems
}

\author{
ZELE Balázs ${ }^{1}$
}

\begin{abstract}
Safety issues in power plants and their direct proportional impact on the safety regulations are increasing significantly nowadays. As a result, fire cases on the way from delivery on the conveyor belt to the final usage in the plant, education of the human resources and improvement of safety regulations are basic key issues. Therefore, in this research I examined the distribution of fire cases and the role of human responsibility through the example of a Hungarian lignite firing power plant by using foreign publications and research.
\end{abstract}

Keywords: power plant safety regulations, fuel supply fields, human responsibility, distribution of fire cases in power plant

The status of energy politics in Hungary and all over the world has been changed in a lot of fields. It is not only relevant in case of general technical improvements, but it also plays a great role in the field of decreasing environmental pollution and development of general standards of the public health system.

"One of the main tasks of energy politics is to convince society about the theoretical and functional ambitions of sustainable energetics. Besides that, another important task of energy politics is to emphasize more carbon-free energy generation in order to maintain the safe provision of the regulations (e.g. $\mathrm{CO} 2$ quota, choosing of firing resource); and of course to foster the foundations of national power plants which are based on national and import coal in order to reduce growth of the average producer price." [1]

Moreover, the fear of energy addiction does not only effect our present, but is based on the past, we clearly have to increase the safe energy provision and in line with that decrease energy addiction. One of the oldest questions of energy maintenance is the energy transformation process in power plants. In the past few years Europe - and of course Hungary also is dealing with the global danger of environmental issues, in which the focus problem is environmental protection. Hungarian energy politics is influenced by the usage of the national resources (e.g. coal/lignite resources) in a larger amount besides the utilization of renewable energy resources. This aspect is based on the ambition of energy generation from basically the usage of national coal resources. If we review the Hungarian resources, we can see that there is a larger amount of lignite in the surrounding Mátra Mountain and black coal at the base of of Mecsek Mountain. In the past years the press was buzzing because of the closure of some mining centers (e.g.: in Mecsek mountain) and then opening them up again. "In the integration of mining centers and power plants, most of the previously functioning mines had been closed down. (In 2003: Balinka, Budaberke storage, Sajómercse, Mákvölgy, Fe-

1 Certified energetic engineer and economist, sales energetic engineer, Siemens Zrt., Óbuda University, Ph.D. candidate, e-mail: zelebalazs@gmail.com 
ketevölgy, Szuhakálló; in 2004 the openwork in Pécs, Mány, Ármin, Lyukóbánya, Lencsehegy. In 2005, the only deep working mining center was Márkushegy, and besides that Visonta, Bükkábrány, and some other little openworks in Borsod and Nógrád county.)” [2]

Despite these, it is sure that the utilization of these resources was not only significant in the past, but it also could be one of the future's unexploited sources. However, appropriate environmental politics should be worked out and utilized, which in my opinion is a step on the right path in order to reach the goals of sustainable energy provision.

The main goal of this current work is to examine and present the contact and presence ratio of causing factors of unregulated fire cases in Hungary's biggest energy provider and distributor power plant which is based on lignite firing. Basically, in this field, besides the coal dust scattering and the technological hazards, it is mainly the human influencing factor which I am going to examine in depth, based on previous experience.

The opinion about coal firing power plants and the applicability of technologies have changed a little bit in the past few years. It is more and more widespread besides firing lignite to utilize biomass resources, too and this movement contributes to coal technology in a more environmentally gentle form. The essence of the technology is combining the appropriate amount and quality of biomass and coal in line with providing the necessary heating value. Based on these, the clearly coal-used technology is behind us, thus taking the national efficiency data into consideration, not only coal usage, but in line with the fact that biomass utilization has also been integrated into the determination of a power plant's effectiveness. (Graph 1)

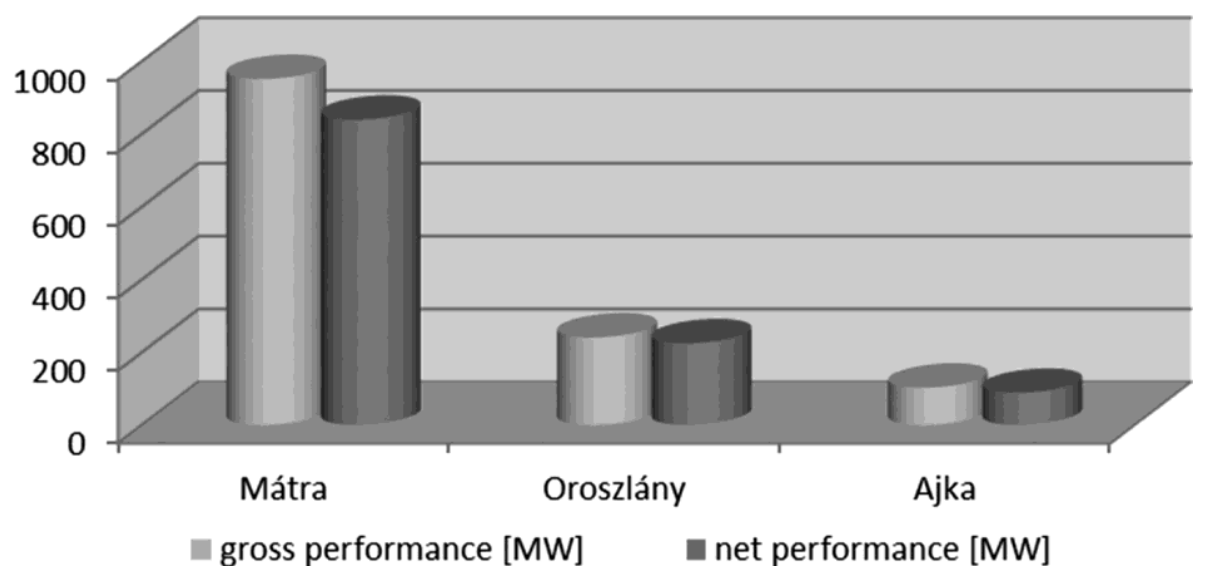

Graph 1. Power Plant energy balance in 2012.

(Own editing - based on MAVIR data. [3] $)^{2}$

2 Note: The ratio of the gross electricity power generation of power plants (MWh/a) and the titular, gross performance (MW) is the utilization of the whole power plant area in performance (h/a). (STRÓBL A.: The analysis of changes in the European and Hungarian electricity-maintenance, providing supply-safety and capacity-research studies.) 
In 2012 the performance of power plants which are based on bio-fuels mixed with mostly carbon sources, can be seen in the first diagram. Based on the sum of these numbers about 1,300 MW performance was within the system, which was a preview of $13 \%$ performance of the year 2012. If we take the 2,000 MW gross performance of Paks Power Plant as a basis, - which gave $45.9 \%$ of the electric power in the whole country for this current year - these data, besides the nuclear energy utilization can be considered significant values owing to the role of the Mátra Power Plant, too.

On the second diagram, we can see the scattering of energy resource utilization in the plants which transform energy from coal and use it, and the role of Mátra Power Plant is quite outstanding. Thus the examination of this project of mine mostly is about "one of the largest electric power generating plants which is also the biggest coal-firing plant in Hungary" based on the official release of the plant. [4] Analyzing the current situation of the country, a more significant changing method is going on, which affects the power generating plants, basically the production of coal-firing power functions. Considering energy policy aspects and EU directives, the energy maintenance of the country should be provided by more and more renewable resources in the near future. It is set officially in the announcement of the European Commission as the following: "the European Union is going on a good path towards reaching its targets, which means that until 2020, 20\% of its energy usage should be provided by renewable energy resources. This initiative is a part of an expansive EU strategy, which is supposed to decrease the climate change. This is absolutely a good thing. Energy from wind, solar, water, tide, geometric and biomass utilization in a larger amount can decrease the European Union's energy import dependence, and it also stimulates innovation and the employment." [5] On the second diagram, based on the 2012 data about the energy consumption of Hungary, continuously based on the previously specified aspects - we can see that how great a role the Mátra power plant has in our country. Besides that we can also see the ratio of other energy resources usage (gas, liquid, etc.), which is on a good path reaching the targets of EU, which helps to maintain a safe and environmentally friendly energy consumption.

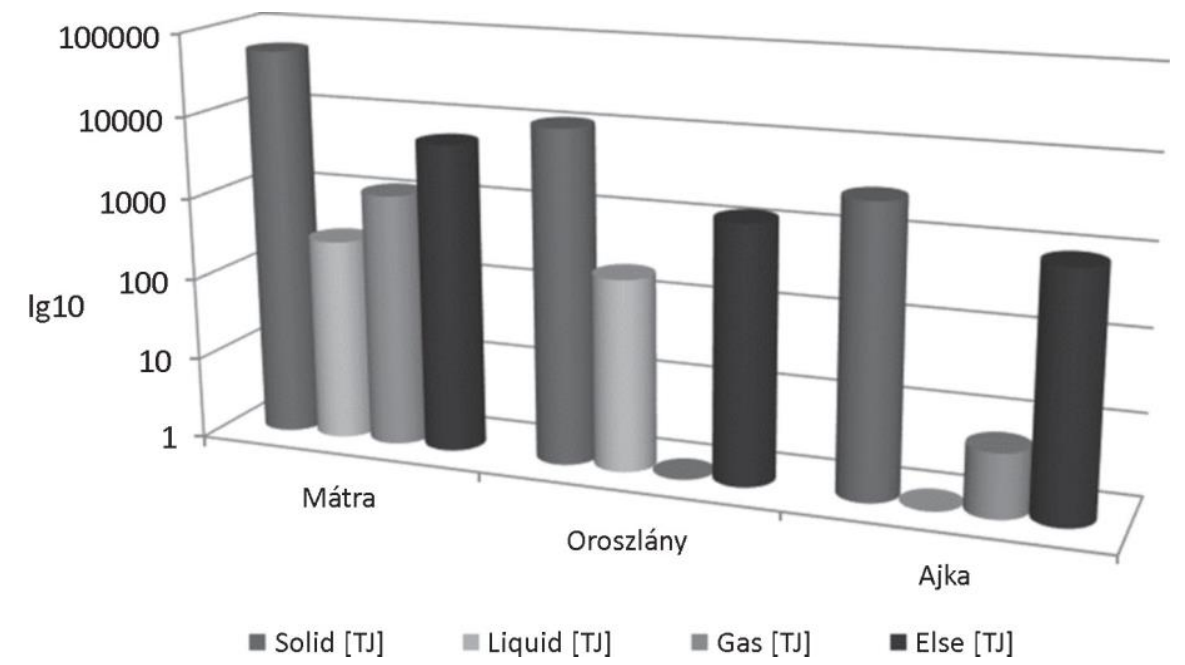

Graph 2. Energy resources utilization "in the biggest power plants remaining today" 2012.

(Own edition - based on MAVIR data. [3]) 
In the further parts of the analysis I focus on the Mátra Power Plant and I examine the case study from the plant, and I draw the final conclusion from them. You can see on the third diagram the statement about the changes in the distribution of the compact energy fuels in the last 10 years. Based on this it can be seen, that besides the considerably balanced lignite usage, the bio and "other" garbage utilization has appeared on the market and in line with that the utilization ratio has also decreased significantly.

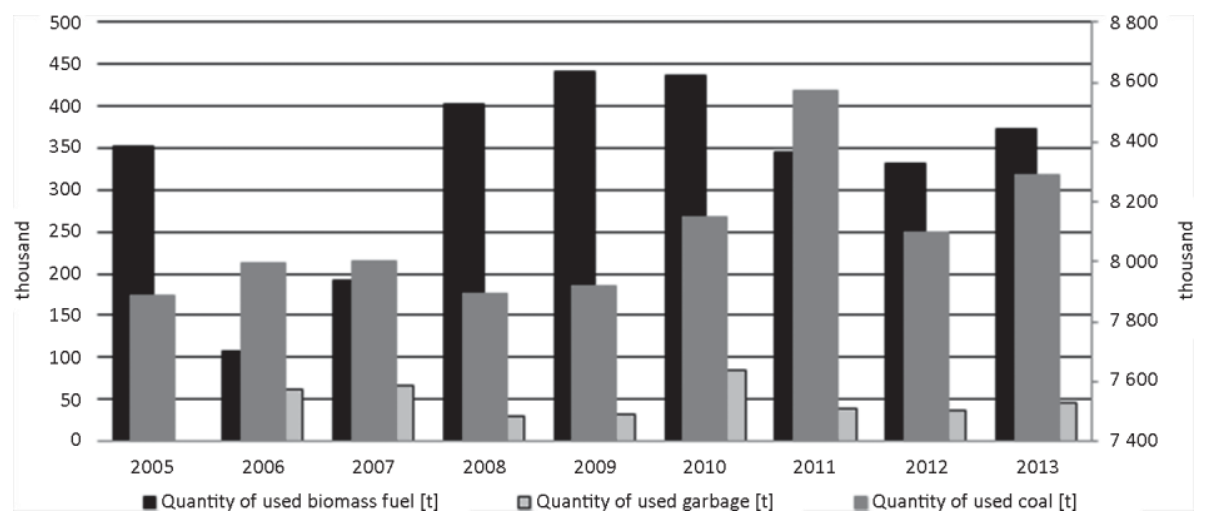

Graph 3. The ratio of used concrete fuels in ME Zrt.

(Own editing - based on Mátra Power Plant Zrt., Department of Thermal Engineering; consultations and reports with associates, January-February 2014.)

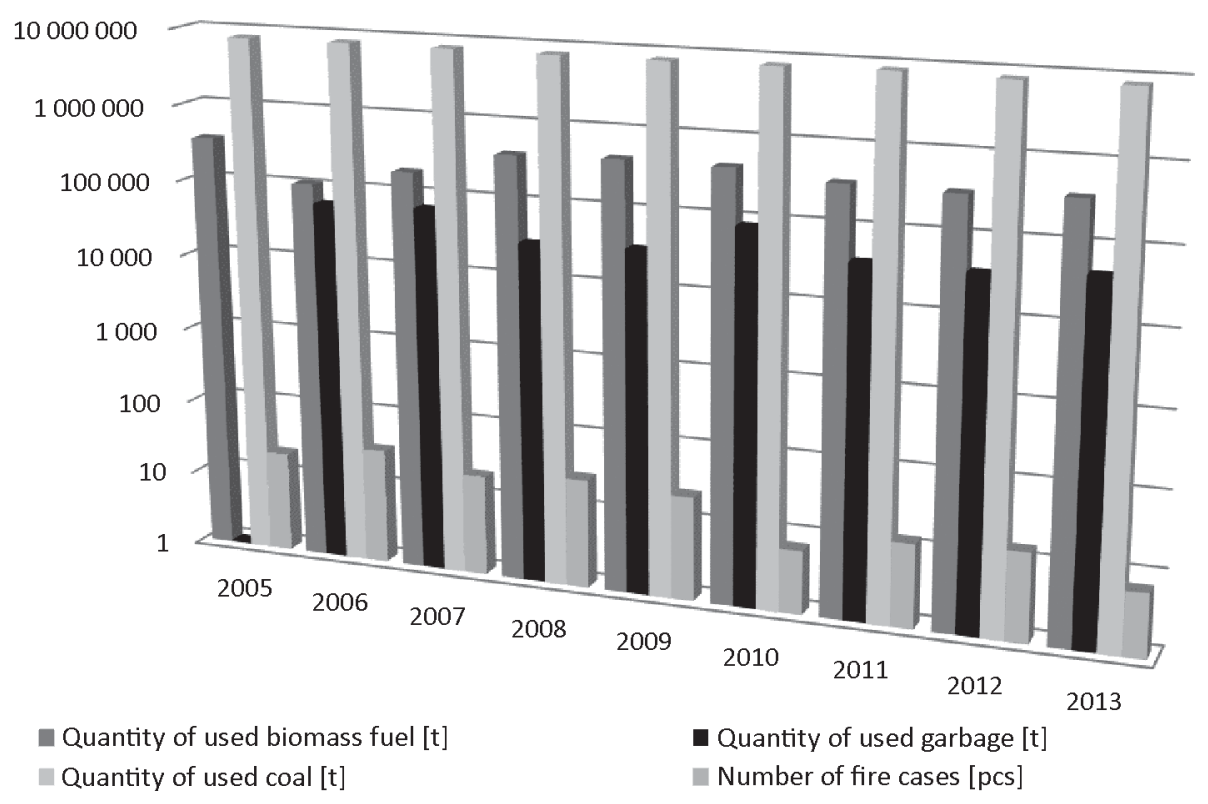

Graph 4. The ratio of concrete fuels and fire cases in ME Zrt.

(Own editing - based on Mátra Power Plant Zrt., Department of Thermal Engineering; consultations and reports with associates, January-February 2014.) 
However, considering the reports of the plant in the examined period of time, the number of fire cases shows us a decreasing tendency. Hereafter, my examination is focusing on the causes, influencing facts and hazards of these fire cases; I also analyze which cases were the most common ones, and of course whether there is coherence between the distribution of indicators.

Based on my previous research and the reports of the plant, in the last 10 years the most common fire cause was the coal dust, the oil-drainage after technical damage and malfunctions, and the fire cases influenced by human errors. This conclusion is also strengthened by my further analysis, too, in which I examine and present the characteristics of fire cases caused by coal dusting process in the line between the coal storage area and the furnace - it can be seen on Graph 5.

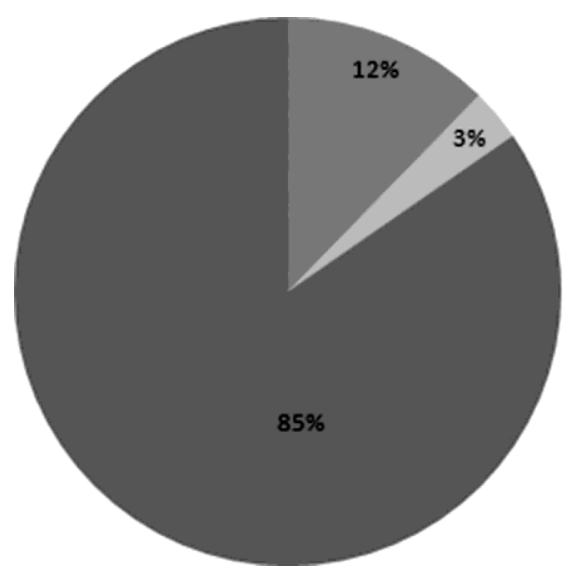

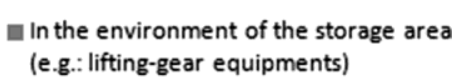

(e.g.: lifting-gear equipments)

In the area of conveyor belt

Inside of the blocks

Graph 5. Distribution of fire cases in the Mátra Power Plant.

(Based on Securing Department data, 2000-2012.) [6]

$85 \%$ of the fire cases were caused by the coal dust spilling/inordinate scattering within the blocks. Other fire cases began directly in the coal storage area, on the conveyor belt and in its surrounding. I confirm these written facts with scientific literature, and besides this I would like to prove my previous statements as well.

Examining international literature resources and American examples, I found an interesting lecture, in which the lecturer called coal "the necessary evil." [7] He meant by this to draw attention to the reaction status of firing coal, thus the thermo process of firing, and especially to the hazardous consequences of the unregulated coal dust burning and explosion effect. "In those places, where the smooth, little granule coal dust can settle, this massed coal dust can ignite - these places can be locations like the equipment beyond the transportation path and the conveyor belt." [7] Besides that, during the transportation of fuel into the furnace, it is also possible to spill and spread dust within the industrial area, which can aggregate and stick into the different tubes and tanks or containers. 
The correspondence between the thickness of the coal dust and the thermo reaction (the process of the ignition) depends on the followings.

$$
T_{e x}=\frac{H \times A_{\text {tot }}}{87,5 \mathrm{p} \times A_{\text {dust }}}
$$

where:

- $\mathrm{T}_{\mathrm{ex}}=$ thickness of coal dust layer, (which contributes to explosion hazard);

- $\mathrm{A}_{\text {tot }}=$ the whole floorspace $\left(20,000 \mathrm{ft}^{3}\right.$ the upper measuring limit); [7]

- $\mathrm{H}=$ the height of floorspace/building ( $\mathrm{ft})$;

- $\mathrm{p}=$ the volume of spilled dust $\left(\mathrm{lb} / \mathrm{ft}^{3}\right)$;

- $\mathrm{A}_{\text {dust }}=$ the surfaces where dust can accumulate within the building $\left(\mathrm{ft}^{2}\right)$.

It is also specified in the publication that human hazards and fire safety protection - (maintenance defaults, smoking prohibitions, compulsory prevention trainings, etc.) - play a great role in the formation of fire cases and explosions caused by coal dust. Thus in the following I examine the scattering and influencing factors of these cases based on the previously mentioned domestic power plant example. Furthermore, as a new theme, I compare the different alternatives with the occurring factors of other causes. However, before I start this, I shall sum up in the first table the causes of the most common fire cases which occurred in this system. Thus the fire cases of the largest Hungarian lignite firing power plant gave the basis to my further examinations. In this process an example, a case study of a Namibian coal firing power plant - with a performance of 150-800 MW - assisted my work. This study categorizes the fire cases caused by mechanical failures into "low hazardous factor" category, however we would rather talk about the more significant influencing factors. [8] Thus probably, the quality, age and other natural factors of fuel - here it is coal - that can be a basis of further analysis. (For example: what kind of influencing factors are there.)

As a consequence, we cannot make further, significant conclusions based on the experience of these one or two plants. However, during a power plant investment in Hungary or abroad in the future, the theories summed up here can be quite usable based on the different firing fuels.

Besides the safety equipment and different solutions, it is worth giving some attention to the factors of the human hazard component, and examining the role of it in the prevention of fire cases and of course the causing influence of it, too.

In the past few years, the plant has deepened the relationship between education and the employees - the decreased number of fire cases also shows that. Thus it can be proven - if we take an equal mechanical failure rate into consideration - that the human hazard factor has influenced the number of occurred fire cases.

3 Note: based on USA measuring system: $\operatorname{yard}^{3}=27 \mathrm{ft}^{3} \approx 0.7646 \mathrm{~m}^{3}$ in SI dimensions. 
ZELE Balázs: Distribution of Fire Cases and the Role of Human Factors in Coal-Firing Power Plants...

Table 1. Distribution of fire cases in the Mátra Power Plant.

(Own edition - based on Securing Department data, 2000-2012.) [6] [9]

\begin{tabular}{|l|c|}
\hline \multicolumn{1}{|c|}{$\begin{array}{c}\text { Causing object of fire cases } \\
\text { (Mátrai Erömü Zrt.) }\end{array}$} & $\begin{array}{c}\text { Number of fire cases (pcs.) } \\
\text { (2000-2012) }\end{array}$ \\
\hline $\begin{array}{l}\text { 1. } \\
\text { Fire cases caused by unregulated coal dust spilling } \\
\text { (coal storage area, within the blocks) }\end{array}$ & 66 \\
\hline $\begin{array}{l}\text { 2. } \\
\text { Fire cases caused by mechanical failures or oil leak } \\
\text { (basically turbine oil leak) }\end{array}$ & 58 \\
\hline $\begin{array}{l}\text { 3. } \\
\text { Fire cases caused by other human errors (e.g.: defaults } \\
\text { of work and fire protection rules during maintenance } \\
\text { welding - assembly scaffold caught on fire) }\end{array}$ & 254 \\
\hline SUM & \\
\hline
\end{tabular}

The number of fire cases based on the influencing factors is present basically because of the coal dust spilling. However, further fire cases are caused by mechanical failures or oil leaks - basically turbine oil leaks and the ambient temperature-caused fires. Finally, the human hazardous facts also influence fire cases, which occurred because of the lack of attention and other inappropriate behavior (e.g. inappropriate application of work and safety protection rules, or not complying with them).

My basic target in this publication was to examine the eventuated different power plant fire cases, thus I analyze the connection between the number of occurred fire cases and the lost production capacity. (Table 2)

Based on the fire examination reports of the plant, I can sum up in the following table the role of important human hazards in different cases, like production capacity and the loss frequency ratio. We can observe the events caused by human hazards in addition to other different plant problems - examining a more than 5-year-interval. (Table 1)

However the larger and more dangerous fire cases were handled in time by the professional personnel and fire protection system quite well and fast, so the further malfunction and production loss was avoided. (Table 2) 
Table 2. Different types and distribution of fire cases 2000-2005. [6] [9] (Own edition.)

\begin{tabular}{|c|c|c|c|c|}
\hline $\begin{array}{c}\text { Main fire cases } \\
\text { (Mátra Power Plant } \\
\text { Zrt.) }\end{array}$ & $\begin{array}{l}\text { Examined } \\
\text { year }\end{array}$ & $\begin{array}{c}\text { Number } \\
\text { of fire } \\
\text { cases }\end{array}$ & \begin{tabular}{l}
\multicolumn{1}{c|}{ Plant } \\
malfunction \\
/ production \\
loss (pcs)
\end{tabular} & $\begin{array}{l}\text { Causes discovered in the } \\
\text { examination }\end{array}$ \\
\hline \multirow{6}{*}{$\begin{array}{l}\text { Caused by unregulated } \\
\text { coal dust distribution } \\
\text { (in the coal storage area } \\
\text { and its surrounding) }\end{array}$} & 2000 & 0 & - & \multirow{6}{*}{$\begin{array}{l}\text { Massed coal dust, sponta- } \\
\text { neous combustion }\end{array}$} \\
\hline & 2001 & 3 & - & \\
\hline & 2002 & 0 & - & \\
\hline & 2003 & 0 & - & \\
\hline & 2004 & 2 & - & \\
\hline & 2005 & 4 & - & \\
\hline \multirow{6}{*}{$\begin{array}{l}\text { Caused by coal dust } \\
\text { spilling (inside the } \\
\text { blocks, on the con- } \\
\text { veyor belt, and its sur- } \\
\text { rounding) }\end{array}$} & 2000 & 2 & - & \multirow{6}{*}{$\begin{array}{l}\text { Massed coal dust, sponta- } \\
\text { neous combustion }\end{array}$} \\
\hline & 2001 & 8 & - & \\
\hline & 2002 & 7 & - & \\
\hline & 2003 & 9 & 1 & \\
\hline & 2004 & 5 & - & \\
\hline & 2005 & 10 & - & \\
\hline \multirow{6}{*}{$\begin{array}{l}\text { Caused by technical or } \\
\text { electronic failure (e.g.: } \\
\text { oil spilling, electronic } \\
\text { malfunction) }\end{array}$} & 2000 & 14 & - & \multirow{6}{*}{$\begin{array}{l}\text { Regular audits (control), } \\
\text { maintenance }\end{array}$} \\
\hline & 2001 & 10 & - & \\
\hline & 2002 & 9 & $4 / 1$ & \\
\hline & 2003 & 2 & - & \\
\hline & 2004 & 5 & - & \\
\hline & 2005 & 4 & - & \\
\hline \multirow{6}{*}{$\begin{array}{l}\text { Caused by other human } \\
\text { failures (e.g.: defaults } \\
\text { of work and fire protec- } \\
\text { tion rules during main- } \\
\text { tenance welding - as- } \\
\text { sembly scaffold caught } \\
\text { on fire) }\end{array}$} & 2000 & 8 & 1 & \multirow{6}{*}{$\begin{array}{l}\text { Human behavior, defaults, } \\
\text { failures, inobservance caus- } \\
\text { es (consequence: person- } \\
\text { alized educational training } \\
\text { program, strict regulation of } \\
\text { open flame usage) }\end{array}$} \\
\hline & 2001 & 2 & - & \\
\hline & 2002 & 3 & - & \\
\hline & 2003 & 4 & - & \\
\hline & 2004 & 5 & - & \\
\hline & 2005 & 6 & - & \\
\hline
\end{tabular}

It can be said, that there is no connection between the production loss and the human influence ratio, consequently the power plant fits the general mechanical and performance regulations from a safety technical point of view, the fire safety system and the general protection mechanism are appropriate. However, the human factor (human hazards) can significantly influence the outcome of the different situations in a positive and also a negative way, thus it can be considered an important influencing factor.

A further consideration is how the human factor and the different safety fire protection equipment are connected and work. 
Based on the plant reports, the following factors contributed to the start of a fire: human behavior, human hazards, inobservance causes. Besides this as a consequence, a development of a new educational training program, the strict regulation of open flame usage or the previously planned work and fire protection training and lectures were the factors which contributed to avoiding the occurrence of fire. Furthermore, a quite common case is hazards caused by coal dust spilling, which needs to be looked out for in the future as well. Actually, it has a quite great role in the international literature, despite the fact that we have to take into consideration the different environmental factors and the technical/mechanical influences.

Finally, I examined those human factors which are the most common cases before and during the formation of a fire.

Human beings, as a basic element of a great whole system, control the technology and regulate the different methods, and can also be a causing component of an accident which disrupts the balance and causes production loss. This is based on a scientific statement in the following wording: human performance basically can influence the complex technical system and the safety and responsibility level of the mechanical equipment. The different safety and risk analyzing reports say that the appropriate handling of the human interactions can be a key factor in understanding the different accidents and their risk components. The aim of the human responsibility analysis (HRA) is to identify the different human interactions, analyze them, and after the thorough examination, build them into the safety regulations, training tutorials. It is not enough to measure the possibility of the success and failure numbers, it is also important to make suggestions in order to develop the human performance.

It is important to emphasize the factors which are more significant in the process of development. These factors can be the following: human and machine harmonization, development of processes and educational training system, harmonization of working expectations with human skills, and the decreasing of the effect of human errors which correlate with each other.

It was also mentioned before, how the systematization of the human capacity and performance can play a significant role. With this, we can avoid the danger on a long-term basis for the safety of complex mechanical equipment caused by human damage factors.

The human factor has also been analyzed in the field of nuclear power plant maintenance and utilization, too, where it had been determined, that "it is a complex system, which is built on technological and human factors, and this duality can be seen in the safety issues as well." [10]

This examination of mine shows the mentioned fire cases between 2000 and 2005, and it can be seen from these cases what kind of causal side-effects were responsible for the fires, besides the basic coal-dust spillage.

The review of these events can be performed in the future, too. Furthermore, to avoid these accidents, it is also suggested that the safety level be raised, and to decrease the human damage factor, as much as possible. The previously mentioned American lecture about the coal-dust combustion has also contributed to this statement. However, for example, it does not write about the distribution ratio, which can be different, depending on the location and different coal-type utilization.

It can be seen, that during the transportation process from the storage area to the furnace it is more common that a fire is formatted because of coal-dust spillage. Furthermore it is also more common that it caused more significant damage and danger - or even a catastrophe inside the blocks in connection with the electric system. 
Searching for international risk analysis and publications I could determine, that there are some statements and examinations, [8] which analyzes the different risk factors within the power plant environment. However, there was no examinations or analysis regarding the fire cases and their later effects caused by events between the transport and burning process whether it was caused by coal-dust spillage, mechanical breakdowns, or human hazards. The decreasing alternatives of the previously examined and analyzed fire cases can be seen in the next graph, which also shows the possible formation places of fires and the most common formation causes in coal-firing power plants, as well. [8]

Location of fire cases, considering the departments within the plant:

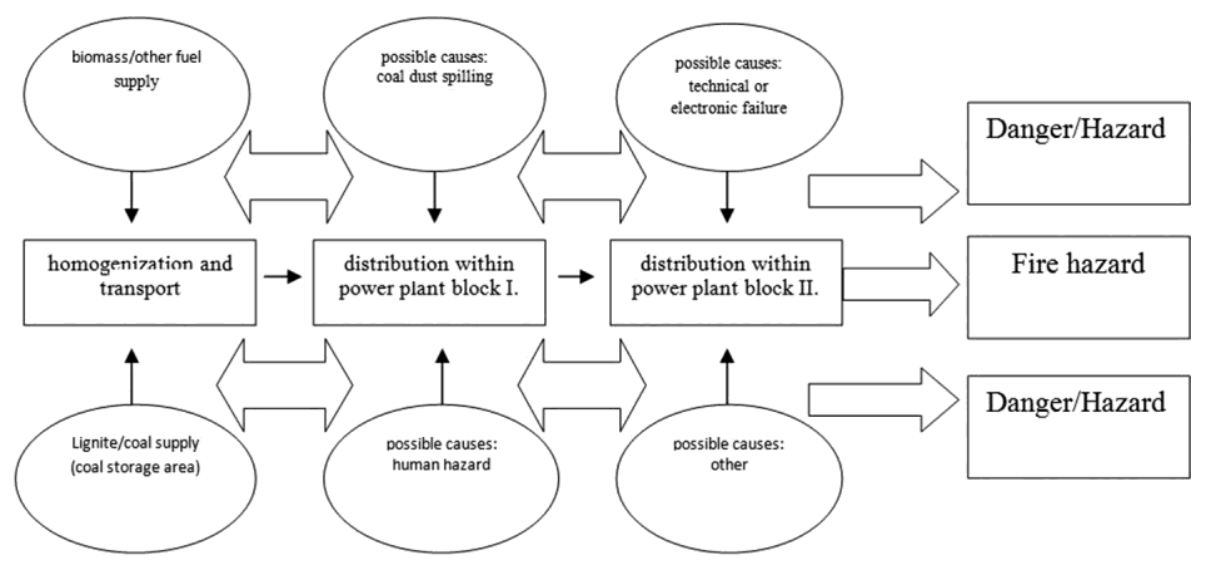

Figure 1. Location of fire cases and the most common causal factors during the resourcetransportation process of the power plant. (Own edition.)

\section{Summary}

In this publication I analyzed and presented the performance and position in the Hungarian energy production structure of domestic combining coal and biomass fired power plants based on today's present knowledge. I confirmed with strategic figures their place in the Hungarian energy industry and in addition to this I demonstrated the different cases in the field of safety and fire protection area. Furthermore I analyzed the hazards induced by engineering operational failure, formation of fire cases and of course the influencing role of human factors. Based on these information I suggested different, safety increasing problem solving possibilities.

I also analyzed the role of the human factor and made an analytical comparison based on international experience and different cases of a Hungarian power plant. Besides the human errors I identified the importance of human positive thinking, the situational awareness and the ability to act fast and accurately in a dangerous situation.

Analyzing the different fire cases the interaction of complex and multiple factors and interacting components can be seen. That is why we can tell that in the whole system the role of human impact role is an important issue besides the general engineering and technical failure influence. Additionally, in my opinion, the domino principle (interacting influence 
ZELE Balázs: Distribution of Fire Cases and the Role of Human Factors in Coal-Firing Power Plants...

role) is also present in these cases, which can be another interesting topic in the future as a new investigation.

All in all, if the number of cases show almost equal distribution, and even if the man-ma- chine-environment system has a huge influencing impact, quality and quantity of the fuel is almost the most important factor, in that the firing process and unregulated, uncontrolled hazards may depend on. To avoid and prevent accidents there are some current developments which can be solutions to the problems, so increased security and fire protection regulations, structural and targeted educational and training policy and good resource management can be key issues besides the general technical compliances and regulations.

\section{References}

[1] ÖSZ J.: Megújuló energiaforrások hasznositása. Budapest: BME Energetic Equipments and Systems Department, s.a. http://energia.bme.hu/ kaszas/Energiapolitika/OszJanos/ Meg\%C3\%BAjul\%C3\%B3\%20energiaforr\%C3\%A1sok.pdf (downloaded: 1412 2013)

[2] KAJATI Gy.: The Post-Socialist Transformation of the Hungarian Electricity Industry. Debrecen: Debreceni Egyetem, 2008. (Ph.D. dissertation)

[3] MAVIR ZRT.: A Magyar Villamosenergia-rendszer közép-és hosszú távú forrásoldali kapacitásfejlesztése. Budapest, 2013. www.mavir.hu/documents/10258/15461/ Forr\%C3\%A1selemz\%C3\%A9s_2013.pdf/0a51f06c-73e7-4607-b582-00d3b1434837 (downloaded: 1201 2014)

[4] MÁTRAI ERÖMÜ ZRT.: Official Webpage (online). www.mert.hu/hu (downloaded: 2501 2014)

[5] EUROPEAN COMMISSION: Uniós terv a megújuló energia-felhasználás növeléséért. 08 06 2012. http://ec.europa.eu/news/energy/120608_hu.htm (downloaded: 1101 2014)

[6] ZELE B., MÁTRAI ERÖMÜ ZRT.: Safety Department - Mechanic Section Reports and Consultations. Reports with Plant Associates. Visonta: January-February, 2014.

[7] CLIFT, J.: Combustible Dust. - Lecture sheet online. Hazard Control Technologies. www.hct-world.com (downloaded: 0401 2014)

[8] NAMPOWER COAL-FIRED POWER STATION, NAMIBIA ENVIRONMENTAL: Environmental and Socio-Economic, Risk Assessment Report. Reference Number: 5975; 15 May 2012. Prepared by Aurecon South Africa (Pty) Ltd. (09 01 2014)

[9] SZABADOS G. T.: Natural and Human Factors at Hazards of Mining Process and their Control - The Role of Environmental and Human Factors in the Mining Hazards and the Protection against them. Miskolc: Miskolci Egyetem, 2011. (Ph.D. dissertation)

[10] KOVÁCS J.: Human Factors Role on Risk Analysis of Complex Systems. Bolyai Szemle, XVI 2 (2007). portal.zmne.hu/download/bjkmk/bsz/bszemle2007/2/bsz2007_2.html (downloaded: 1201 2014) 